\title{
Histological type of lung carcinoma in asbestos cement workers and matched controls
}

\author{
L Johansson, M Albin, K Jakobsson, Z Mikoczy
}

\begin{abstract}
Histological types of lung carcinoma were examined in a case series of workers exposed to asbestos cement dust $(n=29)$ and matched controls $(n=87)$. The proportion of adenocarcinomas was $31 \%$ among the exposed subjects and $15 \%$ among the controls (mid$\mathbf{p}=\mathbf{0} .05)$. Among workers with high exposure the proportion of adenocarcinoma was even higher $(45 \%, 5 / 11$; mid-p $=0.03)$. The proportion of peripheral tumours tended to be higher among exposed cases than controls $(24 v 12 \%$, mid-p $=0 \cdot 12$ ). Lobe of origin did not differ, however, between exposed cases and controls. Thus the study indicates an association between the degree of exposure to asbestos and adenocarcinoma of the lung, and a peripheral rather than central localisation of the tumours, but with virtually the same distribution of lobe of origin as in the general population.
\end{abstract}

Several studies have indicated that subjects with lung carcinoma and exposed to asbestos with or without certified asbestosis have a higher frequency of adenocarcinoma than the general population. ${ }^{1-6}$ Further support is given by Andrion et al who reported that asbestos bodies were significantly associated with adenocarcinoma in persons without known occupational exposure to asbestos. ${ }^{7}$ Other studies have not, however, established differences between asbestos exposed and non-exposed persons in the proportion of adenocarcinoma. ${ }^{89}$ This may be because the particular types of lung carcinomas appear to occur in different proportions depending on type and source of histological specimen, and the proportions may also depend on year of birth and smoking habits.

\footnotetext{
Department of Pathology and Cytology

L Johansson

Department of Occupational and Environmental Medicine, University Hospital, S-221 85 Lund, Sweden

M Albin, K Jakobsson, Z Mikoczy
}

Kreyberg ${ }^{10}$ found a strong association between centrally located carcinomas, mainly small cell carcinoma and squamous cell carcinoma (Kreyberg type I), and smoking. Peripheral tumours (adenocarcinoma, carcinoid, and bronchioloalveolar carcinoma (Kreyberg type II)), on the contrary, were not related to smoking. Today, however, it is well established that the risk for all types of lung carcinomas is enhanced by smoking, although less so for adenocarcinoma. ${ }^{112}$ In the western world, the incidence of adenocarcinoma is increasing in both sexes. ${ }^{13}$ Moreover, in non-smoking (never smoked cigarettes) women, adenocarcinoma constitutes about $70 \%$ of lung carcinomas. ${ }^{14}$ Thus it is important to control for smoking, sex, and year of diagnosis. This has rarely been done in previous studies of histological types of lung carcinomas in populations exposed to asbestos.

It is not clear whether possible differences in histological type between asbestos-induced and other lung carcinomas are present only in asbestotic lungs (induced by the fibrosis), or in non-asbestotic lungs as well. ${ }^{15}$ Moreover, it has been claimed that lobar site of origin may help in the estimate of whether a pulmonary carcinoma is attributable to exposure to asbestos or not. ${ }^{16}$

The question of the histological type of asbestos induced carcinoma has a clear theoretical interest as it may bear upon the mechanism behind the carcinogenesis. Further, it is of importance for principles of workers' compensation, as well as medical surveillance of workers exposed to asbestos.

The aim of the present study was to explore whether subjects exposed to asbestos and with lung carcinoma have an increased proportion of adenocarcinoma, and if a dose-response relation exists between dose of asbestos and histological type of carcinoma.

\section{Material and methods} SUBJECTS

In a cohort of 3144 asbestos cement workers, employed for at least three months in an asbestos cement factory during the period 1907-77, 37 cases of lung carcinoma occurred between 1953 and the end of 1986 in the area served by the Department of Pathology, University Hospital, Lund, Sweden. Of 
these, histopathological material had been preserved for 29 cases (28 men, one woman) (nine bronchoscopic biopsies, five surgical specimens, and 15 necropsies). Two had certified asbestosis (compensated for 33 and $50 \%$ disability) and one had interstitial fibrosis found at the post mortem procedure. Only a few had preserved chest $x$ ray films or lung tissue without tumour, and thus a systematic assessment of interstitial fibrosis was not possible.

Each of the exposed cases was provided with three controls; the three consecutive cases of lung carcinoma in the files of the Department of Pathology matched for type of histopathological sample (bronchoscopic biopsy, surgical specimens, or necropsy), age ( \pm five years), year of diagnosis or death, and sex. In total the material thus consisted of 116 specimens ( 36 biopsies, 20 surgical specimens, and 60 necropsies).

\section{HISTOPATHOLOGICAL PROCEDURES}

The slides were stained with hematoxylin-eosin, van Gieson and periodic acid-Schiff (McManus) + $1-$ diastase, and alcian blue ( $\mathrm{pH} 2 \cdot 5)$. Subsequently, the tumours were classified without knowledge of exposure state, by one of us ( $\mathrm{LJ})$, according to the 1982 revised World Health Organisation classification of lung tumours. ${ }^{17}$

Tumour site was coded as peripheral or central, right or left lung, and lobe of origin (upper, middle, or lower lobe). Tumours with location in both middle lobe (or lingula) and lower lobe were recorded as lower lobe, and those located in both upper and middle lobe (or lingula) were listed as upper lobe. Five tumours in the main bronchus (one exposed subject, four controls) were recorded as upper lobe.

\section{EXPOSURE}

Chrysotile was the major type of fibre ( $>95 \%$ ) used in the asbestos cement plant, together with small amounts of crocidolite and amosite. Average exposures to dust for different jobs and periods were estimated from data on dust concentrations, production, and dust control..$^{18}$ Individual dose estimates were calculated except for two cases (due to missing work histories). The others were divided into two groups, one with high exposure (cumulated dose $>20$ fibre-years $/ \mathrm{ml}(\mathrm{f}-\mathrm{y} / \mathrm{ml})$, range $29-155$, median $42 \mathrm{f}-\mathrm{y} / \mathrm{ml}$ ) and one with low to moderate exposure (cumulated dose $\leqslant 20 \mathrm{f}-\mathrm{y} / \mathrm{ml}$, range $0 \cdot 3-19 \cdot 3$, median $2.5 \mathrm{f}-\mathrm{y} / \mathrm{ml}$ ). The median latency from onset of exposure until time of diagnosis of cancer was 23 years in both groups, and median duration of exposure 17 and two years respectively.

\section{SMOKING HABITS}

Smoking habits were known for 24 of 29 exposed subjects either from earlier interviews or postal inquiries answered by the subject ( 21 persons) or medical records (three persons). When missing, a questionnaire was mailed to their next of kin with questions on smoking (smoker, non-smoker, former smoker at death), year of starting and stopping smoking, and average daily tobacco consumption.Information on the smoking habits among the controls was obtained through postal inquiries, from the persons themselves $(6 \%)$, or from the next of kin (spouse $47 \%$, child $35 \%$, other $12 \%$ ). In the event of non-response or incomplete information, a telephone interview was performed. Information was obtained for 26 of 29 exposed subjects $(90 \%)$ and 66 of 87 controls $(76 \%)$.

\section{STATISTICS}

Distributions between exposed subjects and controls were analysed with a score test in which scores $0-1$ for exposed subjects and controls were assigned for the presence or absence of the specific characteristic. The total score difference between the sets was tested with direct calculation of a mid-p value ${ }^{19}$ (one tailed) after iterated simulation of expected binomial distributions. Differences between high and low to moderate exposure were analysed with the Mann-Whitney non-parametric test of distributions and one tailed $p$ values were calculated.

\section{Results}

Table 1 summarises the results of the histological examination. Table 2 gives the relations between type of specimen (bronchoscopic biopsy, surgical specimen, or necropsy) and histological types of carcinomas. Adenocarcinoma occurred about twice as often among the surgically obtained specimens as among the bronchoscopic biopsies. Squamous cell carcinoma was most frequent among the surgical specimens and least frequent among the necropsies, and small cell carcinoma was rare among the surgical specimens. The proportion of large cell carcinomas was equal among all types of specimens.

Adenocarcinomas were found among $31 \%$ of the exposed subjects and $15 \%$ of the controls (mid$\mathrm{p}=0.05$ ). Restriction of the analysis to the 11 sets in which both exposed and controls were either smokers or former smokers showed the same tendency (mid$p=0.097$ ). Other histological types showed no differences between exposed cases and controls.

Adenocarcinomas constituted $45 \%(5 / 11)$ of the tumours among those with high exposure (mid$p=0.03$, exposed subjects $v$ controls), and $25 \%$ (4/ 16) among those with low to moderate exposure (mid-p $=0.24$, exposed subjects $v$ controls). The difference in the proportion of adenocarcinomas between workers with low to moderate and high exposure was not statistically significant $(p=0 \cdot 2)$.

Lobe of origin (table 3) did not differ between exposed subjects and controls $(66 \% v 70 \%$ in the upper lobe), even when the degree of exposure was 
Table 1 Histological type of lung carcinoma, latency time, age at and year of diagnosis, and smoking information for exposed subjects and controls

\begin{tabular}{|c|c|c|c|c|c|c|c|}
\hline & \multicolumn{4}{|c|}{ Exposed subjects } & \multirow[b]{2}{*}{ Controls } & \multirow[b]{2}{*}{ Total } & \multirow{2}{*}{$\begin{array}{l}\text { Age at } \\
\text { diagnosis } \dagger \\
\text { (median } \\
\text { (range)) }\end{array}$} \\
\hline & $\begin{array}{l}\leq 20 \\
f-y / m l\end{array}$ & $\begin{array}{l}>20 \\
f-y / m l\end{array}$ & All & $\begin{array}{l}\text { Latency } \\
\text { time }(y)^{\star}\end{array}$ & & & \\
\hline $\begin{array}{l}\text { No } \\
\text { Histological type: }\end{array}$ & 16 & 11 & $29 \ddagger$ & & 87 & 116 & \\
\hline $\begin{array}{l}\text { AC }(\text { No }(\%)) \\
\text { SQCC }(\text { No }(\%)) \\
\text { SCC }(\text { No }(\%)) \\
\text { LCC }(\text { No }(\%)) \\
\text { Age at diagnosis } \\
\text { (median (range)) } \\
\text { Year of diagnosis } \\
\text { (median (range)) } \\
\text { Smoking }(\%) \\
\text { Ever smoker }(\%) \S\end{array}$ & $\begin{array}{c}4(25) \\
7(44) \\
3(19) \\
2(12) \\
63 \\
(52-84) \\
1979 \\
(1969-84) \\
14(88) \\
13(81)\end{array}$ & $\begin{array}{l}5(45) \pi \\
4(36) \\
1(9) \\
1(9) \\
69 \\
(52-79) \\
1972 \\
(1953-86) \\
10(91) \\
8(73)\end{array}$ & $\begin{array}{c}9(31) \| \\
11(37) \\
5(17) \\
4(14) \\
64 \\
(52-84) \\
1978 \\
(1953-86) \\
24(83) \\
21(72)\end{array}$ & $\begin{array}{l}34(15-63) \\
21(10-50) \\
22(5-41) \\
32(21-45)\end{array}$ & $\begin{array}{l}13(15) \\
42(48) \\
23(26) \\
9(10) \\
64 \\
(49-84) \\
1979 \\
(1953-87) \\
66(76) \\
62(71)\end{array}$ & $\begin{array}{c}22(19) \\
53(46) \\
28(24) \\
13(11) \\
64 \\
(49-84) \\
1979 \\
(1953-87) \\
92(79) \\
84(72)\end{array}$ & $\begin{array}{l}70(52-84) \\
64(49-84) \\
62(53-81) \\
63(57-84)\end{array}$ \\
\hline
\end{tabular}

^Time from first employment to diagnosis for the exposed, median, and range ( $p=0 \cdot 06, \mathrm{AC} v$ all other types, Mann-Whitney, one tailed).

tAge at time of diagnosis for exposed and controls.

† wo cases with missing dose information.

$\S$ Per cent of cases with information available.

$\pi$ Mid-p $=0.03$, exposed $v$ controls.

Mid-p $=0.05$, exposed $v$ controls.

AC = adenocarcinoma; SQCC = squamous cell carcinoma; SCC = small cell carcinoma; LCC = large cell carcinoma.

considered. Among the exposed subjects, $24 \%$ of the tumours were peripheral $v 12 \%$ for the controls (mid-p $=0 \cdot 12)$. Most of the squamous cell $(98 \%)$ and small cell carcinomas $(93 \%)$ were centrally located whereas $43 \%$ of the adenocarcinomas and $31 \%$ of the large cell carcinomas were peripheral.

The tumour originated in the right lung among $69 \%$ of the exposed subjects and $55 \%$ of the controls (mid-p $=0 \cdot 14$; including one control with tumours in both lungs).

Table 1 gives the latency for the exposed cases ( $p=0.06$, adenocarcinoma $v$ all other types, MannWhitney, one tailed), and the median age at the time of diagnosis for exposed subjects and controls.

\section{Discussion}

Depending on type and source of specimen, various histological types of lung carcinoma occur with different frequencies. Our results are similar to those presented by Ives $e t$ al in a review of several studies (table 2).$^{20}$ It is obvious that matching for source of specimen is necessary. Moreover, even if most lung carcinomas might be referred to one of four major types, ultrastructural studies have allowed a more detailed classification; that is, about $70 \%$ of the large cell carcinomas are adenocarcinomas ultrastructurally. ${ }^{21}$

We found a twofold difference in the proportions of adenocarcinomas between workers exposed to asbestos and controls. Among the exposed subjects the effect was related to degree of exposure; an association not likely to be spurious, because median latency was identical for the two exposure groups, as was median age at diagnosis for the particular lung carcinomas. Our results are in accordance with the findings among asbestos cement workers in Denmark ${ }^{22}$ where the relative risk for adenocarcinoma was higher than for other types of lung carcinomas and increased with duration of employment.

Smoking habits were known for a higher proportion of exposed subjects than controls. Also, the information was obtained from the person himself for a larger proportion of the exposed subjects, thus tending to give a greater precision among these than among the controls. A difference in the precision would, with the assumption of a higher number of

Table 2 Lung carcinoma by type of specimen: bronchoscopic biopsy, surgical specimens or necropsy for exposed subjects and controls in the present study. Reference values (ref) from a review ${ }^{20}$ are also included

\begin{tabular}{|c|c|c|c|c|c|c|c|c|c|c|}
\hline & \multicolumn{3}{|c|}{ Bronchoscopic biopsy } & \multicolumn{3}{|c|}{ Surgical specimen } & \multicolumn{3}{|c|}{ Necropsy } & \multirow[b]{2}{*}{ Total } \\
\hline & No & $(\%)$ & $R e f^{\star}$ & No & $(\%)$ & $\operatorname{Ref}^{\star}$ & No & $(\%)$ & $\operatorname{Ref}^{\star}$ & \\
\hline $\begin{array}{l}\text { AC } \\
\text { SQCC } \\
\text { SCC } \\
\text { LCC }\end{array}$ & $\begin{array}{r}5 \\
18 \\
9 \\
4\end{array}$ & $\begin{array}{l}(14) \\
(50) \\
(25) \\
(11)\end{array}$ & $\begin{array}{r}2-29 \\
36-49 \\
17-34 \\
-\end{array}$ & $\begin{array}{r}5 \\
12 \\
1 \\
2\end{array}$ & $\begin{array}{r}(25) \\
(60) \\
(5) \\
(10)\end{array}$ & $\begin{array}{r}8-33 \\
44-76 \\
3-13 \\
-\end{array}$ & $\begin{array}{r}12 \\
23 \\
18 \\
7\end{array}$ & $\begin{array}{l}(20) \\
(38) \\
(30) \\
(12)\end{array}$ & $\begin{array}{l}25-27 \\
17-35 \\
24-37 \\
-\end{array}$ & $\begin{array}{l}22 \\
53 \\
28 \\
13\end{array}$ \\
\hline Total & 36 & $(100)$ & - & 20 & (100) & - & 60 & (100) & - & 116 \\
\hline
\end{tabular}

${ }^{\star} \mathrm{LCC}$ not included. 
Table 3 Anatomical site (lobe of origin and central/peripheral location) among exposed subjects and referents

\begin{tabular}{|c|c|c|c|c|}
\hline & \multirow[b]{2}{*}{ Controls } & \multicolumn{2}{|l|}{ Exposed subjects } & \multirow[b]{2}{*}{ All } \\
\hline & & $\leqslant 20 f-y / m l$ & $>20 f-y / m l$ & \\
\hline $\begin{array}{l}\text { No } \\
\text { UL }(\text { No }(\%)) \\
\text { LL (No }(\%))\end{array}$ & $\begin{array}{l}87 \\
61(71) \\
22(25)\end{array}$ & $\begin{array}{l}16 \\
11(69) \\
4(25) \\
(95 \% \text { CI } 16-34 \%)\end{array}$ & $\begin{array}{l}11 \\
8(73) \\
2(18) \\
(95 \% \text { CI } 0-41 \%)\end{array}$ & $\begin{array}{l}29 \star \\
19(66) \\
7(24) \\
(95 \% \text { CI } 8-40 \%)\end{array}$ \\
\hline $\begin{array}{l}\text { ML (No }(\%)) \\
\text { UL \& LL (No (\%)) } \\
\text { C/P (No }(\%))\end{array}$ & $\begin{array}{l}4(5) \\
0 \\
77 / 10(88 / 12)\end{array}$ & $\begin{array}{l}1 \\
0 \\
13 / 3(81 / 19)\end{array}$ & $\begin{array}{l}0 \\
1(9) \\
8 / 3(73 / 27)\end{array}$ & $\begin{array}{l}1(4) \\
2(7) \\
22 / 7(76 / 24)\end{array}$ \\
\hline
\end{tabular}

$\mathrm{UL}=$ upper lobe $\mathrm{LL}=$ lower lobe; $\mathrm{ML}=$ middle lobe; $\mathrm{C} / \mathrm{P}=$ central $/$ peripheral $; 95 \% \mathrm{CI}=95 \%$ confidence interval.

^Two exposed subjects with missing dose information.

smokers among the controls with missing information, give a bias towards the null hypothesis.

An increased proportion of adenocarcinoma among asbestos workers might be because adenocarcinoma is more common among subjects with pulmonary fibrosis, regardless of the aetiology, ${ }^{23}$ probably as a consequence of multicentric metaplastic changes (squamous, mucinous, adenoid-cystic lesions) in fibrotic lungs. ${ }^{1}$ This is confirmed by animal studies ${ }^{24}$ and also supported by studies of chrysotile ${ }^{25}$ and amphibole ${ }^{26}$ miners and insulators. ${ }^{27}$ Further, a study of asbestos cement workers ${ }^{28}$ showed that the increase in risk for lung carcinoma was limited to workers with fibrosis diagnosed by chest $x$ ray film (ILO category $\geqslant 1 / 0$ ). This led the authors to conclude that "asbestos is carcinogenic because of its fibrogenicity." The assumption that alveolar epithelial hyperplasia or atypical epithelial hyperplasia is preneoplastic is controversial, however. In a study of such lesions located close to lung carcinomas (mostly peripheral adenocarcinomas) in lungs without fibrosis, transition between hyperplasia and carcinomas could not be proved. ${ }^{29}$

Even if two exposed persons in this study had clinically manifest asbestosis and one had interstitial fibrosis found at a post mortem procedure, it is doubtful whether clinically silent and unrecognised asbestosis or otherwise induced pulmonary fibrosis could explain all the excess of adenocarcinomas. This indicates either that fibrosis is not necessary for asbestos induced adenocarcinoma or that a slight fibrosis is sufficient to induce this carcinoma.

It has been proposed that identification of lobe of origin might be useful for evaluating whether a lung carcinoma is attributable to exposure to asbestos or not. ${ }^{16}$ We found no difference, however, in the interlobar distribution of the carcinomas, either between exposed subjects and controls, or between the groups of exposed subjects with high and low exposure; our figure is close to the $65 \%$ carcinomas in the upper lobes reported for the general population. ${ }^{30}$

Apart from inducing adenocarcinoma in an indirect way by being fibrogenic, asbestos can induce carcinoma in a direct way-for example, it may act as a cocarcinogen, causing short cuts through and destruction of barrier function in the mucous layer of the bronchi..$^{31}$ Perhaps, more importantly, there is now evidence that asbestos is a complete carcinogen. It causes chromosomal changes (aneuploidy and aberrations) affecting either activation of protooncogenes or inactivation of tumour suppressor genes. ${ }^{32}$

Because our study compares relative distributions of types of lung carcinoma in exposed and unexposed cases, whether the risk for other histological types is increased as well, but to a lesser degree, cannot be established.

More tumours were peripheral among the exposed subjects than among the controls, and although not statistically significant, the difference was actually twofold between workers with high exposure and controls. This implies that sputum cytology may be less sensitive, and because of the accuracy of chest $x$ ray films for diagnosis of peripheral tumours such examinations might be more useful for early diagnosis.

In summary our study indicates a higher proportion of adenocarcinomas among workers exposed to asbestos, especially among those with high exposure, compared with a matched series of case controls. The proportion of peripheral tumours tended to be higher among the exposed workers, but lobe of origin did not differ between the two groups. Finally, the results confirm that workers with high exposure in the cohort of asbestos cement workers experience an increased risk of adenocarcinoma of the lung.

This project was supported by grants from the Medical Faculty, University of Lund, the Royal Physiographic Society, Lund, and the Swedish National Association against Heart and Lung Diseases. We also acknowledge valuable help from occupational hygienist Hans Welinder, $\mathrm{PhD}$ who performed the exposure evaluation, laboratory technician Gun Andersson for preparing the specimens, and Ms Katarina Lindén, BSc, for statistical help.

Requests for reprints to: Leif Johansson $\mathrm{MD}$, 
Department of Pathology and Cytology, University Hospital, S-221 85 Lund, Sweden.

1 Heuper WC. Occupational and environmental cancer of the respiratory tract. Recent results in cancer research. Vol 3. New York: Spring-Verlag Inc, 1966:43.

2 Hourihane DO, McCaughey WTE. Pathological aspects of asbestosis. Postgrad Med 1966;42:613-22.

3 Warnock ML, Church AM. Association of asbestosis in bronchogenic carcinoma in a population with low asbestos exposure. Cancer 1975;35:1236-42.

4 Whitewell F, Muriel L, Newhouse L, Bennet DR. A study of the histological cell types of lung cancer in workers suffering from asbestosis in the United Kingdom. Br J Ind Med 1974;31: 298-303.

5 Vena JE, Byers TE, Cookfair D, Swanson M. Occupation and lung cancer risk: An analysis by histological subtypes. Cancer 1985;56:910-7.

6 Adachi S, Takemoto K. Occupational lung cancer: A comparison between humans and animals. Japanese Journal of Industrial Health 1987;29:345-57.

7 Andrion A, Pira E, Fadda T, Mollo F. Lung asbestos bodies and pulmonary cancer in subjects without occupational exposure. Tumori 1982;68:359-64.

8 Kannerstein M, Churg J. Pathology of carcinoma of the lung associated with asbestos exposure. Cancer 1972;30:14-21.

9 Auerbach O, Garfinkel L, Parks VR, Conston AS, Galdi VA, Joubert L. Histologic type of lung cancer and asbestos exposure. Cancer 1984;54:3017-21.

10 Kreyberg L. Histological lung cancer types: A morphological and biological correlation. Acta Pathologica Microbiologica Scandinavica 1962; Supplement 157:1-92.

11 Sobue T, Suzuki T, Horai T, Matsuda M, Fujimoto I. Relationship between cigarette smoking and histological type of lung cancer, with special reference to sex difference. Jpn J Clin Oncol 1988;18:3-13.

12 Lubin JH, Blot WJ. Assessment of lung cancer risk factors by histological category. $J$ Nath Cancer Inst 1984;73:383-9.

13 Linnoila I. Pathology of non-small cell lung carcinoma: New diagnostic approaches. Hematol Oncol Clin North Am 1990; 4:1027-51.

14 Koo LC, Ho J H-C. Worldwide epidemiological patterns of lung cancer in nonsmokers. Int J Epidemiol 1990;19(suppl 1):S14S23.

15 Browne $\mathrm{K}$. Is asbestosis or asbestos the cause of the increased risk of lung cancer in asbestos workers. $\mathrm{Br} \mathrm{J}$ Ind Med 1986;43:145-9.

16 Weiss $W$. Lobe of origin in the attribution of lung cancer to asbestos. $\mathrm{Br} J$ Ind Med 1988;45:544-7.

17 The world health organization histological typing of lung tumours. Am J Clin Pathol 1982;77:123-36.

18 Albin MP, Jakobsson K, Attewell R, Johansson L, Welinder $H$. Mortality and cancer morbidity in cohorts of asbestos-cement workers and referents. Br J Ind Med 1990;47:602-10.

19 StatXact. User manual. Cytel Software Corporation 1989:202-3.

20 Ives JC, Buffler PA, Greenberg SD. Environmental associations and histopathological patterns of carcinoma of the lung: The challenge and dilemma in epidemiologic studies. Am Rev Respir Dis 1983;128:195-209.

21 Hammar S. The use of electron microscopy and immunohistochemistry in the diagnosis and understanding of lung neoplasms. Clin Lab Med 1987;7:1-30.

22 Raffin E, Lynge E, Korsgaard B. Incidence of histological types of lung cancer among employees in the asbestos cement industry in Denmark. Congress communication, 23rd international congress on occupational health, 22-28 September 1990, Montreal, Canada.

23 Kawai T, Yakumaru K, Suzuki M, Kageyama K. Diffuse interstitial pulmonary fibrosis and lung cancer. Acta Pathol Jpn 1987;37:11-9.

24 Davis JMG, Cowie HA. The relationship between fibrosis and cancer in experimental animals exposed to asbestos and other fibers. Environmental Health Perspectives 1990;88:305-9.

25 Liddell FOK, McDonald JC. Radiologic findings as predictors of mortality in Quebec asbestos miners. Br J Ind Med 1980; 37:257-67.

26 Sluis-Cremer GK, Bezuidenhout BN. Relation between asbestosis and bronchial cancer in amphibole asbestos miners. $\mathrm{Br} J$ Ind Med 1989;46:537-40.

27 Kipen HM, Lilis R, Suzuki Y, Valciukas JA, Selikoff IJ. Pulmonary fibrosis in asbestos insulation workers with lung cancer: a radiological and histopathological evaluation. $\mathrm{Br} J$ Ind Med 1987;44:96-100.

28 Hughes $\mathrm{J}$, Weill $\mathrm{H}$. Asbestosis as a precursor of asbestos related lung cancer: results of a prospective mortality study. $\mathrm{Br} J$ Ind Med 1991;48:229-33.

29 Nakanishi K. Alveolar epithelial hyperplasia and adenocarcinoma of the lung. Arch Pathol Lab Med 1990;114:363-8.

30 Byers TE, Vena JE, Rzepka TF. Predilection of lung cancer for the upper lobes: an epidemiological inquiry. J Natl Cancer Inst 1984;134:306-11.

31 Gerde P, Scholander P. A hypothesis concerning asbestos carcinogenicity: the migration of lipophilic carcinogens in adsorbed lipid bilayers. Ann Occup Hyg 1987;31:395-400.

32 Barrett JC, Lamb PW, Wiseman RW. Multiple mechanisms for the carcinogenic effects of asbestos and other mineral fibers. Environmental Health Perspectives 1989;81:81-9.

Accepted 6 January 1992 